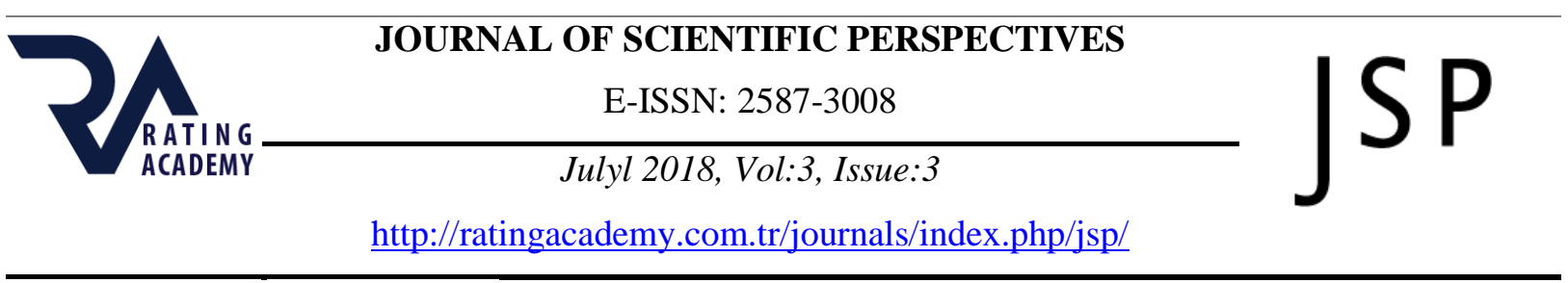

\title{
HISTOPATHOLOGICAL CHANGES IN THE STOMACH MUCOSA OF RATS FED WITH CARPET SHELL CLAM (Ruditapes decussatus)"
}

Dr. Aslı MURATLI

Zübeyde Hanım Application and Research Center, Başkent University, İzmir/Turkey

Dr. Mehmet Riza GEZEN*

Çanakkale Onsekiz Mart University, Vocational College of Health Sciences, Çanakkale, Turkey,

E-mail: $\underline{\text { mrgezen@comu.edu.tr }}$

\begin{tabular}{|c|c|}
\hline ARTICLE INFO & ABSTRACT \\
\hline $\begin{array}{l}\text { Article History: } \\
\text { Received: 05 June } 2018 \\
\text { Accepted: } 13 \text { July } 2018\end{array}$ & $\begin{array}{l}\text { Free radicals are produced in cells by cellular metabolism and exogenous } \\
\text { agents. These specie reacts with biomolecules in cells, including DNA, proteins, } \\
\text { lipids and carbonhydrates. The resulting oxidative damage to DNA, is implicated }\end{array}$ \\
\hline $\begin{array}{l}\text { Keywords: Dardanelles, } \\
\text { Stomach, carpet shell clam, } \\
\text { 8-hydroxy-2' - } \\
\text { deoxyguanosine, } \\
\text { immunohistochemistry }\end{array}$ & $\begin{array}{l}\text { household wastes and pesticides are threats for the aquatic ecosystem. Polluted } \\
\text { water sources are streaming into the seas and cause pollution in these systems. } \\
\text { Dardanelles is exposed to pollution from the Marmara and Black Sea. Our } \\
\text { previous studies demonstrated that the water and mollusc from certain regions of } \\
\text { the Dardanelles contained heavy metal salts. The purpose of the study is to }\end{array}$ \\
\hline $\begin{array}{l}\text { DOI: } \\
\text { 10.26900/jsp.2018342250 }\end{array}$ & $\begin{array}{l}\text { demonstrate DNA damage and the histopathologic changes in the gastric tissues } \\
\text { of rats which are fed with carpet shell clam that are collected from the Çardak } \\
\text { Lagoon (Chanakkale, Turkey). Four groups of rats are included in the study, } \\
\text { group } 1 \text { (n=6), control group fed with standard rat food, group } 2(n=6), 75 \% \\
\text { carpet shell clam and } 25 \% \text { standard rat food daily, group } 3(n=6), 75 \% \text { carpet } \\
\text { shell clam and } 25 \% \text { standard rat food every two days, group } 4(n=6), 75 \% \\
\text { carpet shell clam and } 25 \% \text { standard rat food every three days. After the routine } \\
\text { histopathologic processing all gastric tissue samples are evaluated in terms of } 8 \text { - } \\
\text { hydroxy-2' -deoxyguanosine (8-OHdG) immunoreactivity with light microscopy } \\
\text { and image analysis software. No histopathologic differences found in standard } \\
\text { hematoxylin-eosin stained gastric tissue samples of the control group. Mucosal } \\
\text { specimens of the second, third and fourth groups showed mild mononuclear } \\
\text { inflammation in favor of chronic gastritis. In immunohistochemical staining, } 8 \text { - } \\
\text { OHdG immunoreactivity in gastric epithelial cells. 8-OHdG immunoreactivity } \\
\text { was negative in stomach tissues in all groups. There was no statistically } \\
\text { significant difference between the groups that were fed every day, every other } \\
\text { day and every three days with clam (p>0.05). The results of our studies showed } \\
\text { that rats fed more with carpet shell clam could produce gastritis in the stomach. }\end{array}$ \\
\hline
\end{tabular}

\footnotetext{
* This study is the revised version of the same name paper presented in the "2nd International Rating Academy Congress: Hope" held in Kepez / Çanakkale on April 19-21, 2018
} 


\section{INTRODUCTION}

Free radicals are highly active chemical products that occur in the body during metabolism. The most important free radicals in biological systems are the radicals formed by oxygen (Gulbahar, 2007). Free radicals occur in cells due to endogenous and exogenous sources. Environmental factors such as stress, viruses, infection, exposure to chemicals such as paracuat and alloxan, drug toxications such as pesticides, carbon tetrachloride, paracetamol, ionizing and ultraviolet radiation, air pollutant phytochemicals, cigarette smoke, solvents, cisplatin, antimicrobial agents such as nitrofurantoin, bleomycin, doxorubicin and adriamycin, hyperbaric oxygen, tricyclic antidepressants, metal ions such as iron, copper, cadmium, nickel, chromium and mercury, asbestos fibers, mineral powders, ozone, carbon monoxide, silica, aflatoxin B1 and polychlorinated biphenyl (Fraga et al. 1990; Halliwell, 2000; Williams et al. 2000; Ateş et al. 2004; Burçak et al. 2004; Siomek et al. 2006).

Mechanism of Occurrence of Oxidative Strase-Associated DNA Damage DNA Damage and Causes All changes that occur due to the effects of endogenous or exogenous factors on the molecular integrity of genetic material are called DNA damage. The integrity of genomic DNA is constantly threatened by environmental factors. Changes in DNA structure may occur endogenously during cellular events such as DNA replication and DNA recombination (Kulaksiz et al. 2007). DNA damage is a phenomenon that is common throughout the life of the cell and can lead to mutation, cancer, aging, and ultimately cell death. DNA is constantly exposed to changes by cellular metabolites (ROS) and exogenous agents throughout life. These changes can eventually lead to cellular death in single-celled organisms or degeneration and aging in multicellular organisms (Sancar et al. 2004).

We have identified heavy metals in seawater and many molluscan species that growing in the Dardanelles (Gezen et al. 2011; Gezen et al. 2011; Demir et al. 2011; Özkurnaz et al. 2012). In our previous research have investigated the accumulation of heavy metals in the carpet shell clam, great scallops, sea snails and oysters from the Dardanelles Umurbey region. In this research, $\mathrm{Zn}$ in carpet shell clams, $\mathrm{Zn}$ and $\mathrm{Mn}$ in great scallops, $\mathrm{Zn}$ in oysters, $\mathrm{Al}, \mathrm{Zn}, \mathrm{Fe}, \mathrm{Cu}$ and $\mathrm{Mn}$ in sea snails found the metals as high. If the same zone is in seawater, the $\mathrm{Zn}$ level is high. In sea chestnuts growing in Dardanells, the values of $\mathrm{Al}, \mathrm{Zn}$, and $\mathrm{Fe}$ in samples taken from Gelibolu Hamzakoy station are high. $\mathrm{Al}$ and $\mathrm{Fe}$ values were higher in samples taken from Çardak region. Al, Fe and $\mathrm{Zn}$ values were higher in samples taken from Umurbey region. $\mathrm{Al}, \mathrm{Fe}$ and $\mathrm{Zn}$ values were higher in samples taken from Çamburnu region (Gezen et al. 2011). In our previous research have investigated the accumulation of heavy metals in the carpet shell clam, great scallops, sea snails and oysters from the Dardanelles Karacaören region. In this research, Al, $\mathrm{Zn}$ and Fe in carpet shell clams, $\mathrm{Zn}$ and $\mathrm{Mn}$ in great scallops, $\mathrm{Zn}$ in oysters, $\mathrm{Al}, \mathrm{Zn}, \mathrm{Fe}, \mathrm{Cu}$ and $\mathrm{Mn}$ in sea snails found the metals as high (Gezen et al. 2011; Demir et al. 2011; Özkurnaz et all. 2012).

There is no research revealing histopathologic changes in the stomach tissues of living beings fed with carpet shell clam collected from the Çardak Lagoon (Çanakkale, Turkey). The purpose of the study is to demonstrate DNA damage and the histopathologic changes in the gastric tissues of rats which are fed with carpet shell clams that are collected from the Çardak Lagoon (Çanakkale, Turkey).

\section{MATERIAL AND METHODS}

\subsection{Ethics Statement}

The study protocol was approved by the Çanakkale Onsekiz Mart University Ethics Committee for Animal Research (Protocol number: 2010/09-03). 


\subsection{Animal Model}

A total of 24 male Wistar albino rats, weighing 290-310 g, were used in the study. The rats were kept for 30 days under appropriate conditions of temperature/humidity and a 12-h light cycle while being provided sufficient water and feed. The rats were randomly selected and divided into 4 groups. For the first study group (n: 6), was the control group; standard rat diet was given every days. For the second study group (n: 6), 75\% carpet shell clam $+25 \%$ standard rat diet standard rat feeds were given daily. For the third study group (n: $6), 75 \%$ carpet shell clam $+25 \%$ standard rat diet was given every two days. Standard rat diet was given the other day. For the fourth group (n: 6), $75 \%$ carpet shell clam $+25 \%$ standard rat diet was given every three days. Standard rat diet was given the other two day.

Rats were fed twice daily for 30 days at $15 \%$ of their weight every morning and evening at the same time. The carpet shell clam given as food to the rats were removed from the Çardak Lagoon (Çanakkale, Turkey), (Figure 1). Average $30 \pm 10 \mathrm{~g}$ weight were selected. After the beaks were overcooked, the meat broke off and the meat at 100 degrees was dried.

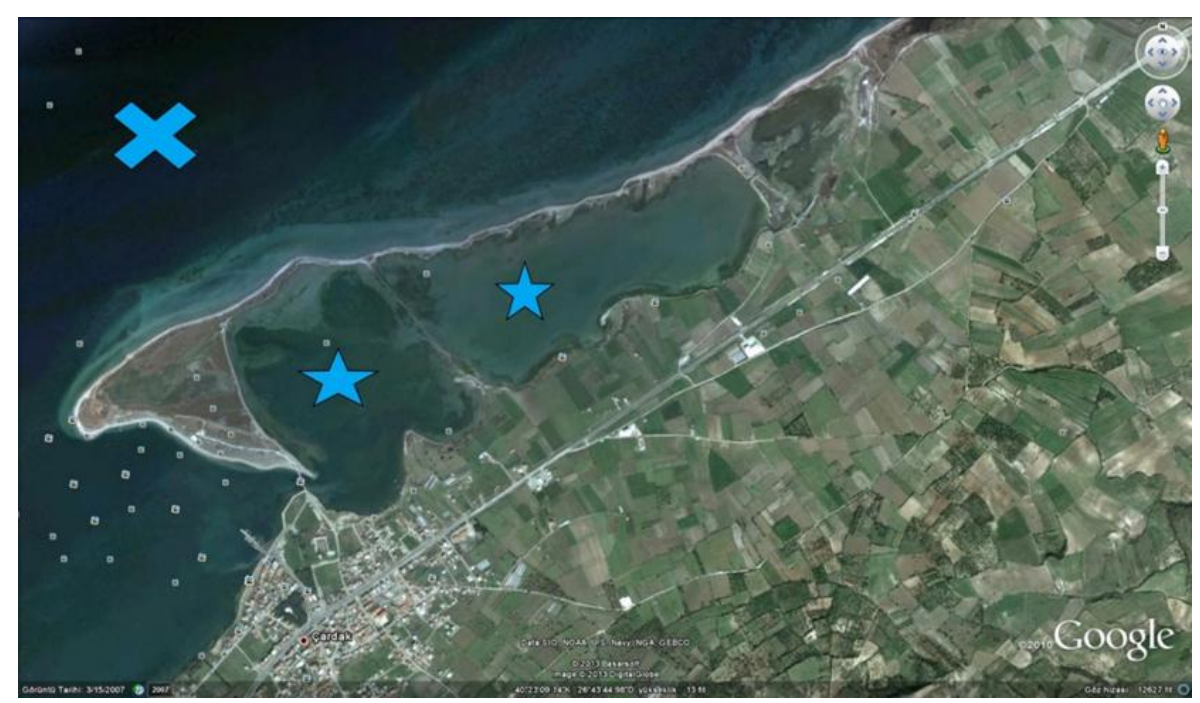

Figure 1. The area where the carpet shell clam are collected. Star: Çardak Lagoon (Çanakkale, Turkey); Crossed: Dardanelles

It was weighed into each rat's weight and $10 \mathrm{mg} / \mathrm{kg}$ intraperitoenal ketamine, and 20 $\mathrm{mg} / \mathrm{kg}$ of xylazine $2 \%$ were anesthetized. The rats were anesthetized and then sacrificed. After the rats have received the stomachs other organs were also taken for further research.

\subsection{Histological evaluation}

The stomach tissues were maintained in immunofix (Leica) for 24 hours for histopathological examination. The paraffin embedded stomach tissues were stained with hematoxylin and eosin $(H \& E)$ at a thickness of 5 microns. Immunohistochemical staining method was applied by cutting the paraffin embedded stomach tissues 3 microns in thickness. For 8-hydroxydeoxyguanosine (8-OHdG) staining, tissue samples were incubated at $37^{\circ} \mathrm{C}$ in Proteinase K (dilution 1: 30, Millipore Corporation) for $40 \mathrm{~min}$. and then waited in the laboratory until the room was warmed up. The LAB-SA Detection System, (Histostain-Plus Bulk Kit, Invitrogen) was applied to determine immunohistochemical localization of 8hydroxydeoxyguanosine $(8-\mathrm{OHdG})$ in tissues. Slides were incubated with polyclonal goat anti-8-Hydroxydeoxyguanosine (8-OHdG, Millipore Corporation) antibody, which was diluted 1:200 for the stomach tissue, for 30 minute at room temperature. Diaminobenzidine- 
tetra hydrochloride (DAB, Invitrogen Corporation) was used as the colorant. Also Mayer's hematoxylin stain was used as a nuclear counterstain.

Dye samples were evaluated on the Zeiss AXIO Scope 1 brand research microscope. Analysis of 8-OHdG immunoreactive cells in the stomach tissue was performed using the Leica LAS V3.8 image analysis system. Five of the sections from the blocks containing the stomach tissues of all the rats in all groups were stained. From the stained sections, 1000 cells were counted and immunoreactive cells were identified among these cells. Tosun et al. (2006); Bakır et al. (1996); Avunduk et al. (2000) for this purpose;

Immunopositive cells / Total cell count (1000) -------- x $100 \%=\ldots \ldots \%$ formula were used .

\subsection{Statistical analysis}

SPSS 15 version was applied for the statistical evaluation of the results obtained with the applied formula. Kruskal-Wallis Test was used for nonparametric tests to determine the differences between survivin immunoreactivity groups. The difference between the groups was considered significant in the results of $\mathrm{p}<0.05$.

\section{RESULTS}

There was no significant change in the staining of the stomach of the rats in the first group with Hematoxylin \& Eosin (Figure 2).

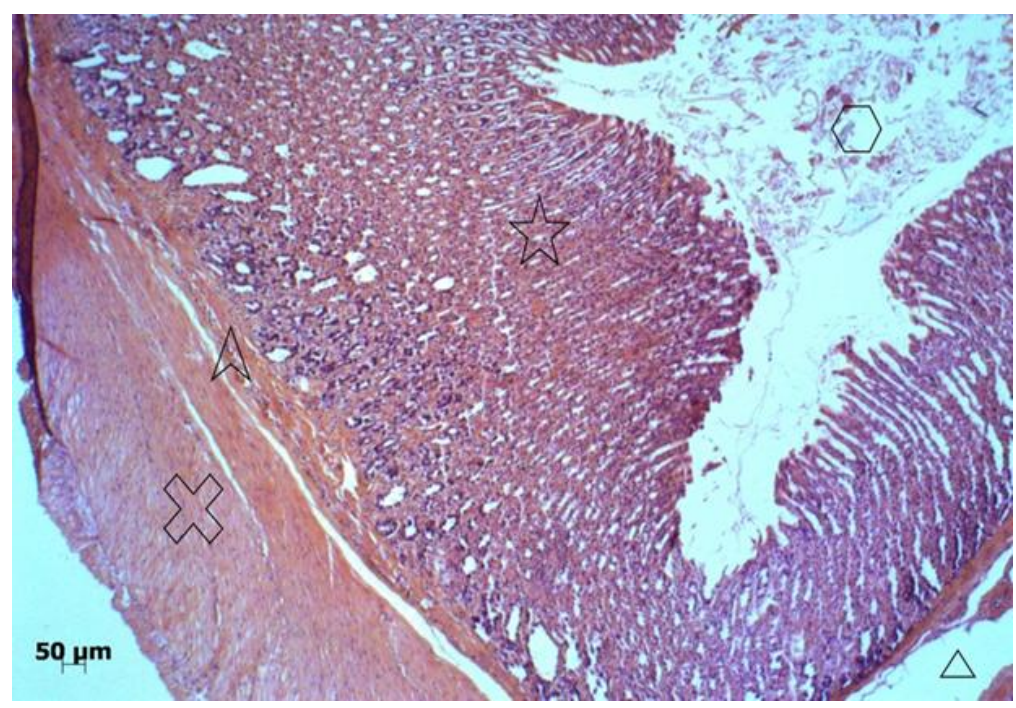

Figure 2. For the first study group was the control group; standard rat diet was given every days. Rat stomach, (H.E.x5). Star: Lamina propria mucosa; Pointed arrow: Lamina muscularis mucosa; Arrow head: Lamina submucosa; Crossed: Tunica muscularis; Hexagon: Gastric lumen

In the second group, there were active chronic gastritis findings in the rat gastric mucosa (Figure 3). Mononuclear inflammatory cells were observed lamina propria mucosa, lamina muscularis mucosa and lamina submucosa. 


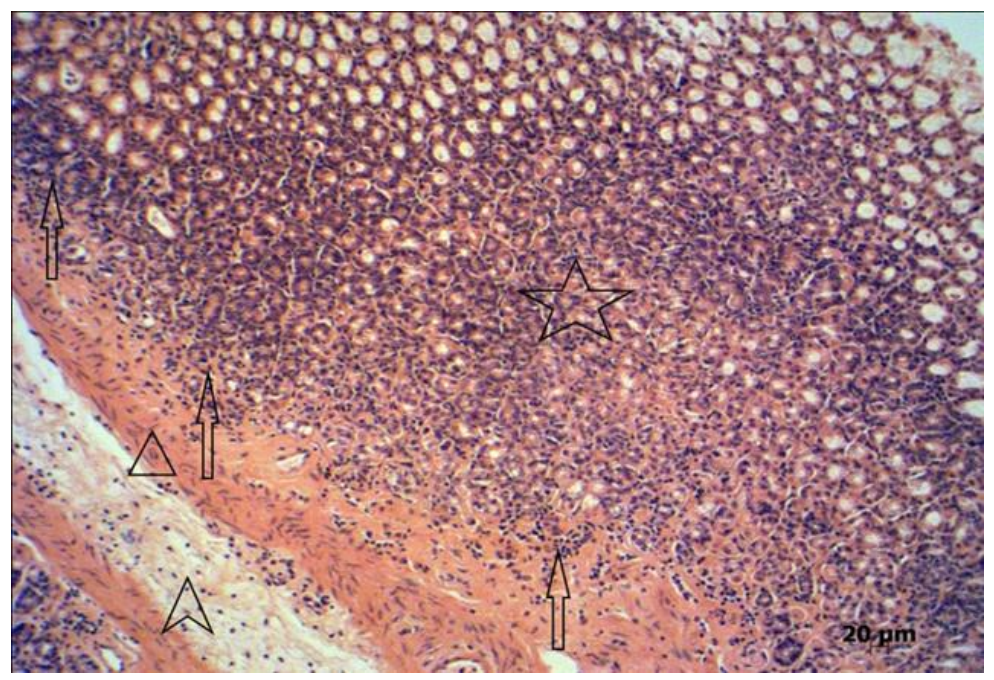

Figure 3. For the second study group; $75 \%$ carpet shell clam $+25 \%$ standard rat diet standard rat feeds were given daily. Rat stomach, (H.E.x10). Star: Lamina propria mucosa; Arrow head:

Lamina muscularis mucosa; Pointed arrow: Lamina submucosa; Arrows: Mononuclear inflammatory cell.

In the third group, mononuclear inflammatory cells were observed in some areas of the lamina muscularis mucosa, more in the lamina propria mucosa (Figure 4).

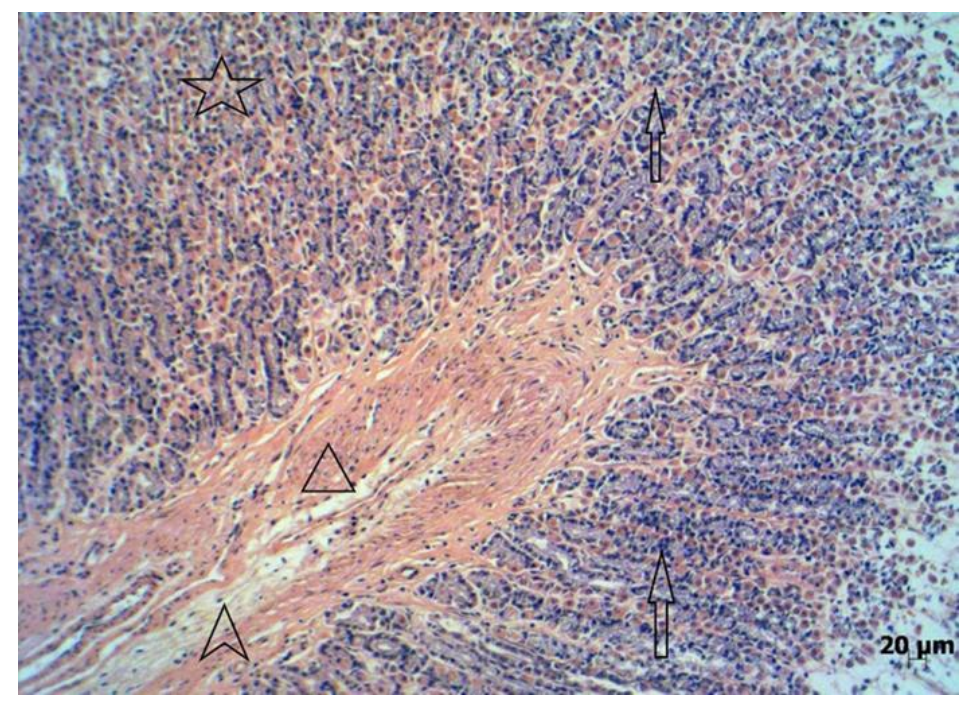

Figure 4. For the third study group; $75 \%$ carpet shell clam $+25 \%$ standard rat diet was given every two days. Standard rat diet was given the other day. Rat stomach, (H.E. x10). Star: Lamina propria mucosa; Arrow head: Lamina muscularis mucosa; Pointed arrow: Lamina submucosa; Arrows: Mononuclear inflammatory cells.

In the fourth group, while mononuclear inflammatory cells were observed mildly on the lamina propria mucosa, lamina muscularis and lamina propria were more common on the border. (Figure 5). 


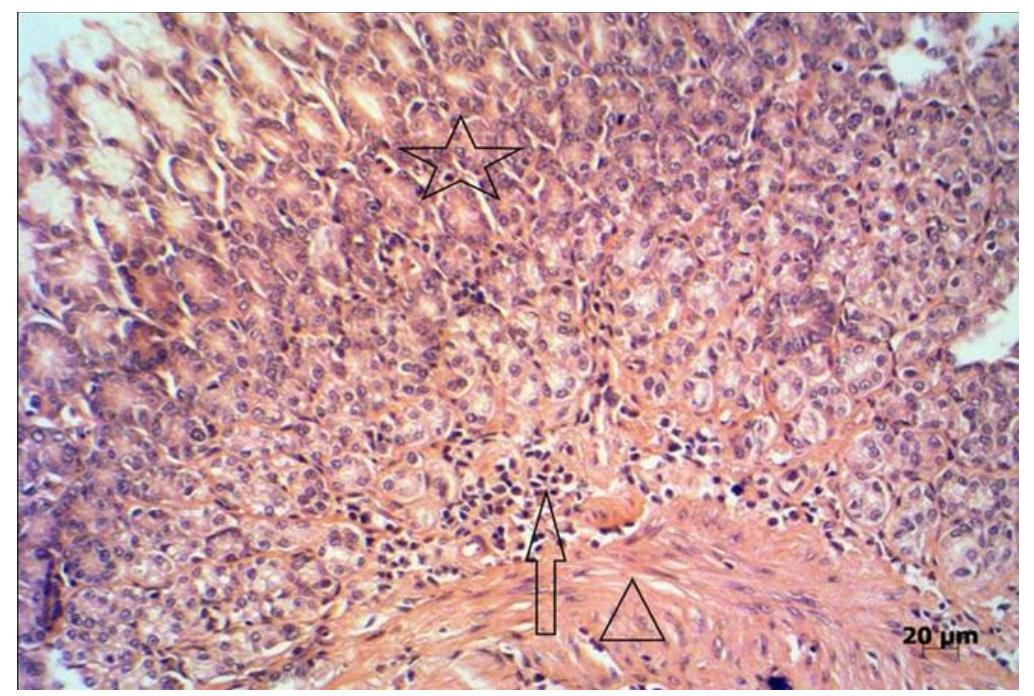

Figure 5. For the fourth group; $75 \%$ carpet shell clam $+25 \%$ standard rat diet was given every three days. Standard rat diet was given the other two day. Rat stomach, (H.E.x20). Star: Lamina propria mucosa; Arrow head: Lamina muscularis mucosa; Arrow: Mononuclear inflammatory cells

8-OHdG immunoreactivity was negative in stomach tissues in all groups. No significant differences were detected between groups in immunohistochemical staining with $8-\mathrm{OHdG}$ (Figure 6).

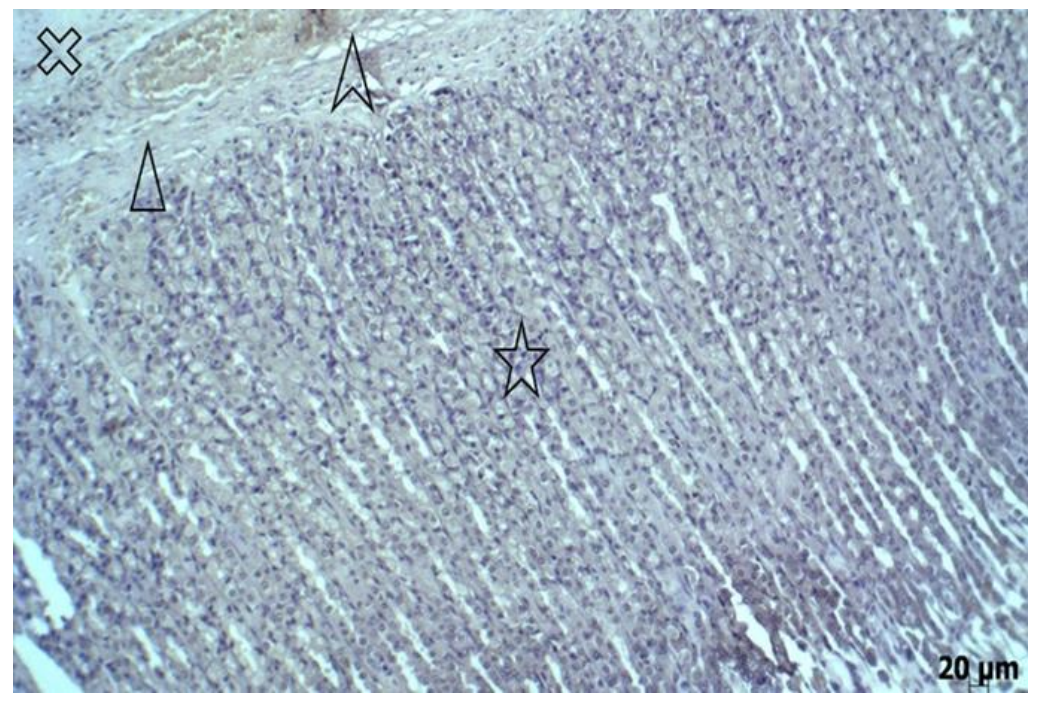

Figure 6. For the second study group; $75 \%$ carpet shell clam $+25 \%$ standard rat diet standard rat feeds were given daily. Rat stomach. (8-OHdGx10). Star: Lamina propria mucosa; Arrow head: Lamina muscularis mucosa; Pointed arrow: Lamina submucosa; Crossed: Tunica muscularis.

\section{DISCUSSION}

In this study, we found mononuclear inflammatory cell growth and chronic gastritis in the gastric tissues of rats which are fed with carpet shell clam that are collected from the Çardak Lagoon (Çanakkale, Turkey).

Heavy metals are commonly found in the environment and diet. In small amounts they are required for maintaining good health but in larger amounts they can become toxic or dangerous. Heavy metal toxicity can lower energy levels and damage the functioning of the 
brain, lungs, kidney, liver, blood composition and other important organs. Long-term exposure can lead to gradually progressing physical, muscular, and neurological degenerative processes that imitate diseases such as multiple sclerosis, Parkinson's disease, Alzheimer's disease and muscular dystrophy. Repeated long-term exposure of some metals and their compounds may even cause cancer (Jarup, 2003). The toxicity level of a few heavy metals can be just above the background concentrations that are being present naturally in the environment. Hence thorough knowledge of heavy metals is rather important for allowing to provide proper defensive measures against their excessive contact (Ferner, 2001). Heavy metals are toxic because they may have cumulative deleterious effects that can cause chronic degenerative changes (Ibrahim et al. 2006), especially to the nervous system, liver, and kidneys, and, in some cases, they also have teratogenic and carcinogenic effects (IARC, 1987). Long-term exposure to heavy metals such as mercury $(\mathrm{Hg})$, lead $(\mathrm{Pb})$, chromium $(\mathrm{Cr})$, cadmium $(\mathrm{Cd})$, arsenic $(\mathrm{As})$, copper $(\mathrm{Cu})$, vanadium $(\mathrm{V})$, nickel $(\mathrm{Ni})$ chronic inflammation, cardiac, pulmonary and neurological effects and some cancers (Nieboer et al. 2013; Mantovani et al. 2008; Clarkson, 2002). Recent studies have shown that vascular effects of heavy metals may contribute to a variety of pathologic conditions including diabetes mellitus and hypertension (Navas-Acien et al. 2005; Prozialeck et al. 2006). In this study, we found mononuclear inflammatory cell growth and chronic gastritis in gastric mucosa of rats fed with carpet shell clam. Findings by some investigators that heavy metals may cause inflammation support our findings.

Reactive oxygen species cause more than 20 oxidative base damage products in DNA (Dizdaroğlu, 1998). Among these bases, 8-hydroxy-2'-deoxyguanosine (8-OHDG) is highly sensitive and the most common oxidative DNA damage (De Martinis et al. 2002). Some researchers have found that heavy metal salts can cause DNA damage (Fraga et al. 1990; Halliwell, 2000; Williams et al. 2000; Ateş et al. 2004; Burçak et al. 2004; Siomek et al. 2006). Immunohistochemical staining methods are used to detect cell and tissue damage (Gezen, 2017). In this study, we investigated whether or not to produce DNA damage by feeding the carpet shell clam containing heavy metal salts to rats. However, 8-OHDG was found to be negative in the gastric mucosa of all groups in our study. It is thought that heavy metals in low levels (NOEL) in the grains do not cause DNA damage.

However, the histopathologic changes in the gastric mucosa of the carpet shell clam fed rats assumes that gastrointestinal diseases are highly likely in people who consume these carpet shell clam. The authors think that care must be taken when consuming this kind of seafood.

\section{Acknowledgements}

This research was supported by the ÇOMÜ BAP committee (Project Number: 2010/245).

\section{Footness}

* At the time of this research, she was working at Department of Pathology of Çanakkale Onsekiz Mart University. 


\section{REFERENCES}

ATES, I., SUZEN, H.S., AYDIN, A., KARAKAYA, A., 2004, The Oxidative DNA Base Damage In Testes Of Rats After Intraperitoneal Cadmium Injection. Biometals, 17(4), $371-7$.

AVUNDUK, M.C., TAVLI, S., YOL, S., TAVLI, L., YAVUZ, A., GUNGOR, S., YILMAZ, O., 2000, Mide karsinomlarında hücre proliferasyon belirleyicisi olarak PCNA, Ki 67 ve agNOR kullanımı, Ankara Üniversitesi Tıp Fakültesi Mecmuası, 53(1), 11-15.

BAKIR, K., KAPUCUOĞLU, N., BULBUL, H.D., 1996, PCNA (Proliferating Cell Nuclerar Antigene) immunohistokimyasal boyanmas1 ve agNORs'un meme karsinomunda prognozu belirlemedeki rolü, Türk Patoloji Dergisi, 12(1), 35-38.

BURCAK, G., ANDICAN, G., 2004, Oksidatif DNA Hasarı ve Yaşlanma, Cerrahpasa J Med, 35(4), 159-169.

CLARKSON, T.W., 2002, The three modern faces of mercury, Environ Health Perspect, $110,11-23$.

DE MARTINIS, B.S., DE LOURDES PIRES BIANCHI, M., 2002, Methodology For Urinary 8-hydroxy-2'-deoxyguanosine Analysis By HPLC With Electrochemical Detection, Pharmacol Res, 46(2), 129-31.

DEMIR, N., GEZEN, M.R., BALLI, M., 2011, Çanakkale Boğazı'nın Karacaören Kiyısındaki

Deniz Suyu ve Bazı Yumuşakçalarda (Bivalvia ve Gastropoda) Ağır Metal Düzeylerinin Araştırılması, Ekoloji 2011 Sempozyumu, 5-7 Mayıs, Düzce, 177.

DIZDAROGLU, M., 1998, Facts About the Artifacts in the Measurement of Oxidative DNA Base Damage by Gas Chromatography-mass Spectrometry, Free Radic Res, 29(6), 551-63.

FERNER, D.J., 2001, Toxicity, heavy metals, eMed J. 2(5), 1.

FRAGA, C.G., SHINENAGA, M.K., PARK, J.W., DEGAN, P., AMES, B.N., 1990, Oxidative Damage to DNA During Aging: 8-hydroxy-2'-deoxyguanosine in Rat Organ DNA and Urine, Proc Natl Acad Sci USA, 87(12), 4533-7.

GEZEN, M.R., DEMIR, N., ÇETIN, M., 2011, Çanakkale Boğazı'nın Umurbey Kıyısındaki Deniz suyu ve Bazı Yumuşakçalarda (Bivalvia ve Gastropoda) Ağır Metal Düzeylerinin Araştırılması. Ekoloji 2011 Sempozyumu, 5-7 Mayıs Düzce, 178.

GEZEN, M.R., DEMIR, N., ÇETIN, M., BALLI, M., 2011, Çanakkale Boğazı'ndaki DenizKestanesi (Paracentrotus lividus)' nin Ağır Metal Düzeyleri Üzerinde Bir Araştırma, Ekoloji 2011 Sempozyumu, 5-7 Mayıs Düzce, 176.

GEZEN MR, 2017. Histopathological Research and Diagnosis of Important Paiting Methods, JSP, 1(1): 23-27.

GULBAHAR, O., 2007, Protein Oksidasyonunun Mekanizması, Önemi ve Yaşlılıkla İlişkisi.Turkish Journal of Geriatrics, 10(1), 43-48, 2007.

HALLIWELL, B., 2000, Why and How Should We Measure Oxidative DNA Damage in Nutritional Studies? How Far Have We Come? Am J Clin Nutr, 72(5), 1082-7. 
IARC (International Agency for Research on Cancer) 1987, Monographs on the Evaluation of the Carcinogenic Risk of Chemicals to Humans: Arsenic and Arsenic Compounds (Group 1) Vol. 7. Lyon, France: World Health Organization; 100-106.

IBRAHIM, D., FROBERG, B., WOLF, A., RUSYNIAK, D.E., 2006, Heavy metal poisoning: clinical presentations and pathophysiology, Clinics in Laboratory Medicine, 26(1), 67-97.

JÄRUP, L., 2003, Hazards of heavy metal contamination, Br Med Bull, 68(1), 167-182.

KULAKSIZ, G., SANCAR, A., 2007, Nükleotid Eksizyon Onarımı ve Kanser, Turk J Biochem, 32(3), 104-111.

MANTOVANI, A., AllavenA, P., SICA, A., BALKWILL, F., 2008, Cancer-related İnflammation, Nature, 454, 436-44.

NAVAS-ACIEN, A., SILBERGELD, E.K., SHARRETT, A.R., CALDERON-ARANDA, E., SELVIN, E., GUALLAR, E., 2005, Metals in urine and peripheral arterial disease, Environmental Health Perspectives, 113(2), 164-169.

NIEBOER, E., TSUJI, L.J., MARTIN, I.D., LIBERDA, E.N., 2013, Human biomonitoring issues related to lead exposure. Environ Sci Process Impacts, 15: 1824-9.

OZKURNAZ, G., DEMIR, N., 2012, Umurbey Bölgesi'nden (Çanakkale) Toplanan Mytilus galloprovincialis ve Pecten maximus Dokularında Ağır Metal Birikiminin İncelenmesi. 21. Ulusal Biyoloji Kongresi, İzmir, Türkiye, 3-7 Eylül, 880-881.

PROZIALECK, W.C., EDWARDS, J.R., WOODS, J.M., 2006, The vascular endothelium as a target of cadmium toxicity, Life Sciences, 79(16), 1493-1506.

SANCAR, A., LINDSEY-BOLTZ, L.A., UNSAL-KAÇMAZ, K., LINN, S., 2004, Moleculer mechanisms of mammalian DNA repair and the damage checkpoints, Annu Rev Biochem, 73, 39-85.

SIOMEK, A., TUJAKOWSKI, J., GACKOWSKI, D., ROZALSKI, R., FOKSINSKI, M., DZIAMAN, T., ROSZKOWSKI, K., OLINSKI, R., 2006, Severe oxidatively damaged DNA after cisplatin treatment of cancer patients, Int J Cancer, 119(9), 2228 30 .

TOSUN, E., TOSUN, M., AVUNDUK, M.C., 2006, Hücre Çoğalma Belirleyicilerinin Meme İnfiltratif Duktal Karsinomlarında Progrostik Amaçlı Kullanımı, Optimal Tıp Dergisi, 19(2), 27-40.

WILLIAMS, G.M., JEFFREY, A.M., 2000, Oxidative DNA Damage: Endogenous and Chemically Induced, Regul Toxicol Pharmacol, 32(3), 283-92. 
MURATLI \& GEZEN / Histopathological Changes in the Stomach Mucosa of Rats Fed with Carpet Shell Clam (Ruditapes decussatus) 